\title{
A Comparative Morphological Approach to Class Maintaining Derivational Affixes in English and Kurdish
}

\author{
Saza Ahmed Fakhry Abdulla and Muhsin Hama Saeed Qadir \\ Department of English, College of Languages, University of Sulaimani, Sulaimani, Kurdistan Region - Iraq
}

\begin{abstract}
This paper is a comparative morphological study of some class maintaining derivational affixes that do not alter the grammatical categories lexemes in Standard English and Central Kurdish from the standpoints of Generative Morphology. For the comparative analysis of the two languages, some of the derivational affixes that form new meanings from the existing lexemes and retain the grammatical categories of the newly derived lexemes have been classified. The main aim of the study is to identify the points of similarity and difference of class maintaining derivational affixes in both languages. The findings indicate that in the addition of nominal affixes, English and Kurdish are similar in that 'concrete nouns' could remain concrete nouns, as well as could convert into abstract nouns by adding certain affixes. In English, a prefix can also be added to a concrete noun to derive a new concrete noun, whereas in Kurdish, only a prefix can be added to an abstract noun to form a concrete noun. In the addition of adjectival affixes, both languages are similar in that adjectives can derive new adjectives by attaching some prefixes and some suffixes to the existing lexemes. In English, the cardinal numbers remain cardinals when the suffixes -teen and -ty are attached to them, whereas in Kurdish the only rare case can be seen when the suffix $-a$ is attached to the two cardinal numerals hawt/ haft 'seven' and hašt 'eight'. The suffixes $-t h$ in English and -(h)am and -(h)amin in Kurdish can be attached to the cardinal numbers to form the ordinal numbers.
\end{abstract}

Key words - Affixation, Class maintaining affixes, Derivation, Derived lexemes, Lexemes.

\section{INTRODUCTION}

In this paper, those classes of affixes that do not change the grammatical categories but the meaning of the newly derived lexemes have been examined in Standard English and Central Kurdish. A comparative approach is used to analyze class maintaining derivational affixes in the two selected languages to identify the points of similarity and difference of those affixes that maintain classes of the lexemes. This paper consists of five sections. Section one is an introduction. Section two involves the methodology which includes the qualitative method of research, research questions and procedures.

Sections three and four present a theoretical framework of class maintaining affixes in English and Kurdish where the derivational morphology in relation to the classification of class maintaining derivational affixes was identified followed by analysis and discussion. Section five aims at identifying the points of similarity and difference of class maintaining derivational affixes in both selected languages whereby the original contribution of this work was presented followed by the main findings.

\section{Methodology}

The selected method of this paper is a morphological comparative approach of class maintaining derivational affixes in English and Kurdish. The research questions of this paper are as follows:

1. What are the points of similarity and difference between Standard English and Central Kurdish as far as class maintaining derivational affixes are concerned?

2. Can class maintaining derivational affixes be attached to the classes of nouns, adjectives, verbs and numerals to derive new lexemes in Standard English and Central Kurdish?

To answer the above research questions, the below steps have been followed:

- reviewing previous studies related to derivational morphology in English and Kurdish specifically the internal structure of morphemes, affixes, roots, etc.

- discussing affixation and its types in relation to class maintaining category in both languages.

- grouping the most common usable class maintaining derivational affixes in accordance with their types in both languages for the purpose of analyzing them.

Journal of University of Human Development

Volume 6 No. 4(2020); DOI: 10.21928/juhd.v6n4y2020.pp25-34

Regular research paper: Received 29 September 2020; Accepted 9 November 2020; Published 16 November 2020

Corresponding author's e-mail: saza.fakhry@univsul.edu.iq, mohsin.saeed@univsul.edu.iq

Copyright @ 2020 Saza Ahmed Fakhry Abdulla, Muhsin Hama Saeed Qadir. This is an open access article distributed under the Creative

Commons Attribution License (CC BY-NC-ND 4.0) 
- classifying the class maintaining derivational affixes into nominal, adjectival, verbal and numeral.

- examining those affixes that retain the grammatical categories in each separate section.

- analyzing the internal structure of the word classes into their component parts.

- comparing class maintaining derivational affixes in the two languages by identifying points of similarity and difference according to the created groups in sections three and four of this paper.

The meanings of the affixes, the existing lexemes, as well as the newly derived lexemes were taken for the English section form Oxford Advanced Learner's Dictionary (2015) and for the Kurdish section from The Sharezoor Kurdish English Dictionary (2000). These references have not been cited with each given affix and given lexeme due to the word limit of the paper.

\section{Class Maintaining Derivational AfFiXes IN STANDARD ENGLISH}

\section{A. Theoretical Framework}

Derivational morphology is a branch of morphology which studies roots, stems, bases, morphemes, types of morphemes, prefixes, suffixes, morphological rules and word formation in English (Bauer, 1983, p. 20). Morphemes can be divided into free that can stand alone and bound that must be attached to another morpheme. For example, the noun tenant 'a person who occupies land' is a free morpheme; when the suffix $-\boldsymbol{c y}$ 'state of being' is added to it, it derives another noun tenancy 'position of land'. Thus, the suffix -cy is a bound morpheme.

In morphology, class maintaining derivational affixes attribute in the creation of new lexemes (Clark et al., 1986, p. 27) by adding a new lexical meaning to a free base. New words can be derived by attaching derivational affixes to a base. For instance, the bound morpheme -hood 'state of being' can be added to a noun adult 'grown person', a 'complex noun' adulthood 'the state of being an adult' will be formed. This bound suffix could be attached to nouns like brotherhood, motherhood, boyhood, parenthood, etc. Derivation is the word formation process in which a derivational affix is attached to the base of a word to create a new word. Deriving new words in a language can rely on a process called affixation. Affixes are morphemes that are "attached to some other morpheme or morphemes such as a root or stem or base" (Katamba, 1993, p.44). Affixes can be divided into prefixes and suffixes.

In English, prefixes are derivational affixes that would rarely alter the grammatical category of the word, but provide various lexical meanings. For example, agree 'have the same opinion' is a 'verb'; and disagree (meaning, the opposite of agree'), is also a 'verb'. Hence, prefix such as dis- 'the opposite of', is called class maintaining derivational prefix (Somathasan, 2018, p. 2).

According to Dupanovic (2019, p.78), the prefixes de-, dis-, in-, non-, un-, etc. can be classified both as "negative and reversative". The opposite prefixes in-, im- and $\boldsymbol{i r}$ - can be attached to adjectives like correct, possible, and regular to derive opposite adjectives incorrect, impossible and irregular. Other instances can be shown with the prefix il- which means 'not'. This prefix can be attached to the adjective logical 'wellreasoned' to derive illogical which means the opposite meaning of logical. Moreover, the noun slave 'bondservant' becomes slavery 'the state of being a slave' when the nominal suffix is attached to it. The vast majority of prefixes do not change the syntactic category of their base words and most of the prefixes are class maintaining (Bauer, 1983, pp.124, 216). According to Katamba, derivational affixes create new words by "changing the meaning of the base to which they are attached" with no changes in "its grammatical categories" (1993, pp. 47-50). In order to specify "which morpheme a particular affix belongs to, it is crucial to realize "the base to which it attaches because the same phonological form may represent different morphemes depending on the base with which it co-occurs" (Katamba, 1993, p.49). For instance, the prefix un- 'not' when it is attached to an adjective healthy 'in good physical condition', it forms another adjective unhealthy 'in poor health'. Both lexemes belong to the lexical category of 'adjectives'.

Katamba (1993, pp.47-50) also indicates that the change "caused by a derivational suffix" can be minor that may "shift a base to a different sub-class within the same boarder wordclass" as it can be seen with the suffix -dom 'the condition or state of' when it is attached to a noun like king 'supreme ruler' to form the noun kingdom 'a country or territory ruled by a king'. According to Somathasan class maintaining derivational suffixes are those "affixes which are added to an existing lexeme. As a result, a new lexeme is formed, but the grammatical category of both lexemes remains the same" (2018, p.3). Thus, class maintaining derivational affixes can generate nouns from nouns, adjectives from adjectives, verbs from verbs that retain their syntactic categories and change the meaning of the derived lexemes. For instance, the word child is a 'noun', when the suffix - hood 'state of being' is attached to it, it becomes childhood 'the state or period of being a child'. Both words, the root child and the derived one childhood are two different words having the same word class but different meanings. Some derivational affixes have a major role in maintaining the class category of the existing lexemes. For instance, the lexeme write is a 'verb'; rewrite (meaning, 'writing again') is also a 'verb'. Here, the prefix re-changes only the meaning of the word, not the grammatical category (Somathasan, 2018, p. 2).

The following derivational affixes include the most common affixes in English that maintain the category of the word classes and change the lexical meanings of the new lexeme. Some of the examples given below are taken from (Umera-Okeke, 2007, pp. 9-35 and Leningrad, 1986, p. 99) in the formation of the given lexical categories:

\section{1) Noun Forming Affixes}

Certain nouns remain nouns by adding the following affixes (Stageberg, 1981, p.157; Katamba, 1993, p.49; Umera-Okeke, 2007, p.9). The following Table (1) includes class maintaining affixes that create nouns and allow morphologists to have a clear understanding of the following prefixes and suffixes that contribute in deriving new words: 
Table (1)

Examples of Noun Forming Affixes

\begin{tabular}{|c|c|c|c|c|c|}
\hline Suffix & Meaning & Examples & Suffix & Meaning & Examples \\
\hline -hood & $\begin{array}{l}\text { 'express } \\
\text { state' }\end{array}$ & childhood & $-i s t$ & $\begin{array}{c}\text { 'someone } \\
\text { concerned } \\
\text { with } \\
\text { something } \\
\end{array}$ & novelist \\
\hline -ship & $\begin{array}{c}\text { 'state or } \\
\text { condition' }\end{array}$ & $\begin{array}{c}\text { scholarshi } \\
p\end{array}$ & -ster & $\begin{array}{c}\text { 'a person } \\
\text { associated } \\
\text { with' }\end{array}$ & youngster \\
\hline -let & 'small' & booklet & $-i s m$ & $\begin{array}{l}\text { 'indicating } \\
\text { behavior' }\end{array}$ & heroism \\
\hline -ling & 'small' & duckling & $-e e r$ & $\begin{array}{c}\text { 'a person } \\
\text { who is } \\
\text { concerned } \\
\text { with' }\end{array}$ & auctioneer \\
\hline -age & $\begin{array}{c}\text { 'state, act, } \\
\text { or result } \\
\text { of }\end{array}$ & parentage & -ess & $\begin{array}{l}\text { 'indicating } \\
\text { a female' }\end{array}$ & lioness \\
\hline -dom & $\begin{array}{c}\text { 'the } \\
\text { condition } \\
\text { or state } \\
\text { of' }\end{array}$ & kingdom & -ade & $\begin{array}{l}\text { 'a drink } \\
\text { made of a } \\
\text { particular } \\
\text { fruit' }\end{array}$ & lemonade \\
\hline$-f u l$ & $\begin{array}{c}\text { 'as much } \\
\text { as will } \\
\text { fill' }\end{array}$ & spoonful & -ite & $\begin{array}{c}\text { 'a person } \\
\text { associated } \\
\text { with' }\end{array}$ & laborite \\
\hline -ette & 'smaller' & novelette & -(e)ry & $\begin{array}{c}\text { 'denoting } \\
\text { occupatio } \\
\text { n' }\end{array}$ & pottery \\
\hline$-y$ & $\begin{array}{c}\text { characteri } \\
\text { zed by }\end{array}$ & monarchy & $-c y$ & $\begin{array}{l}\text { 'rank or } \\
\text { office of' }\end{array}$ & magistracy \\
\hline Prefix & Meaning & Examples & Prefix & Meaning & Examples \\
\hline dis- & 'not' & dis-order & $e x-$ & 'former' & ex-wife \\
\hline
\end{tabular}

The suffixes mentioned in the above table, -dom 'the condition or state of', -ship 'state of being', -hood 'express state' -age 'state, act or result of', and -ism 'indicating behavior' can be attached to the 'concrete nouns' king, scholar, child, parent and critic, respectively to derive the 'abstract nouns' kingdom, scholarship, childhood; parentage; and criticism.

Some affixes including $\boldsymbol{e x}$ - 'former', $\boldsymbol{- f u l}$ 'as much as will fill', and -(e)ry 'denoting occupation', convert 'concrete nouns' into new 'concrete nouns' when they are attached to 'the nouns' wife, spoon, and pot, to derive 'concrete nouns' ex-wife, spoonful, and pottery.

\section{2) Adjective Forming Affixes}

The followings are the most common affixes im- 'not', in'not', ir- 'not', un- 'not', pre- 'before', anti- 'against', -ish 'resembling', -ster 'denoting a person having a particular quality'. These affixes are attached to a base or a root of the adjectives, polite, regular, happy, cautious, social, green, and young, to derive newly formed adjectives, impolite, irregular, unhappy, precautious, antisocial, greenish and youngster.
3) Verb Forming Affixes

Prefixes including ad- 'towards', re-'again', dis- 'not', col'with, together', pre-'before', un- 'not', pro- 'back', mis- 'the opposite of', be- 'about' are attached to verbs such as join, gain, educate, please, locate, judge, cover, claim, apply and speak to drive verbs like adjoin, regain, reeducate, displease, collocate, prejudge, uncover, proclaim, misapply and bespeak. According to Bauer (1983, p. 223), no apparent suffixes will attach to verbs to derive new verbs.

\section{4) Numeral Forming Affixes}

In English, the suffixes -teen and -ty can be attached to cardinal numerals four and seven to create newly derived cardinal numbers fourteen and seventy. The cardinal number eight can also be converted into ordinals when the suffix $-\boldsymbol{t h}$ is attached to it to derive the ordinal number eighth.

\section{B. Analysis and Discussion}

Affixes are classified as nominal, adjectival, verbal and numeral. The following affixes create nouns from nouns, verbs from verbs, adjectives from adjectives, and numerals from numerals. These groups of affixes do not change the class membership of the newly derived words but rather change the lexical meaning of the derived lexemes as summarized below:

\section{1) Nominal Affixes}

In English, the existing nouns retain the grammatical categories of the new nouns when the following affixes are added to them as summarized in the groups below:

Group 1: concrete nouns remain concrete nouns by adding the following suffixes to them:

\begin{tabular}{|c|c|c|c|}
\hline $\mathbf{N}$ & & Meaning & \\
\hline & & & \\
\hline & $\begin{array}{l}\text {-ency } \\
\text {-ism }\end{array}$ & $\begin{array}{r}\text { 'eq } \\
\text { 'indice }\end{array}$ & heroi \\
\hline
\end{tabular}

\begin{tabular}{|c|c|c|c|}
\hline Prefix & Meaning & Concrete Noun & Concrete Noun \\
\hline & 'former' & wife & ex-wife \\
\hline
\end{tabular}

The emboldened item president is a 'noun', when the suffix -ency 'state of being' is attached to it, it becomes presidency which is also a 'noun'. The changes occur when the suffix is added to the existing lexeme. The noun president means "a person in charge of organization (Oxford Advanced Learner's Dictionary, 2015). The newly derived lexeme refers to the period of time somebody holds as a president.

Group 2: concrete nouns can be changed into abstract nouns by adding the below suffixes to them:

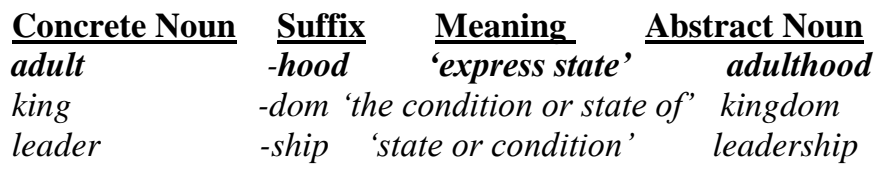


As shown in the above-mentioned group, the emboldened item adult is a 'noun', when the suffix -hood 'express state' is attached to it, it becomes adulthood which is also a 'noun'. The changes occur only in the meaning of the two lexemes. The existing lexeme means "a fully grown person who is legally responsible for their action" and the new derived lexeme refers to "the state of being adult" (Oxford Advanced Learner's Dictionary, 2015). Moreover, in the nominal affix category, the word leader is a 'noun', when the suffix -ship is attached to it, it becomes leadership. Both words, the root leader and the derived one leadership are two different words having the same word class but different meanings. The noun leader refers to a person who leads a group of people in an institution or in a government, whereas the newly derived noun leadership refers to the state or position of being a leader (Oxford Advanced Learner's Dictionary, 2015).

\section{2) Adjectival Affixes}

Prefixes such as dis-, in-, im-, il- and $\boldsymbol{i r}$ - can be added to adjectives such as honest, credible, polite, logical and resistible, to derive the opposite meanings of those adjectives dishonest, incredible, impolite, illogical, and irresistible.

The word honest is an 'adjective', when the prefix dis- 'not' is attached to it, it becomes dishonest. Both words, the root honest and the new derived one dishonest are two different words belonging to the word class of adjectives. They both convey opposite meanings. The adjective honest gives the meaning of 'telling the truth without cheating the other parties', whereas the new derived adjective dishonest means 'the state of being not honest with the intention of tricking other individuals'. Although newly derived adjective dishonest indicates the opposite meaning of the original adjective honest but they still belong to the same syntactic category.

\begin{tabular}{|c|c|c|}
\hline Adjective & $\underline{\text { Suffix }}$ & Adjective \\
\hline $\begin{array}{l}\text { green } \\
\text { dead }\end{array}$ & $-l y^{-i s h}$ & $\begin{array}{l}\text { 'somewhat, rather' } \begin{array}{r}\text { greenish } \\
\text { deadly }\end{array} \\
\text { like' }\end{array}$ \\
\hline
\end{tabular}

The emboldened word green is an 'adjective' when the suffix -ish 'somewhat, rather' is attached to it, it becomes greenish. Both words, the root green and the new derived one greenish are two different words belonging to the category of adjectives but they convey to somehow extent different meanings. The adjective green is a color that is similar to a grass or the leaves of most plants and trees, whereas the new derived adjective greenish refers to fairly green color (Oxford Advanced Learner's Dictionary, 2015).

\section{3) Verbal Affixes}

The category of verbs remains verbs by adding the following prefixes to the verbs followed:

\begin{tabular}{|c|c|c|c|}
\hline Prefix & Meaning & Verb & Verb \\
\hline$\overline{r e-}$ & 'again' & $\overline{\text { organize }}$ & reorganize \\
\hline $\begin{array}{l}\text { un- } \\
\text { mis- } \\
\text { dis- }\end{array}$ & $\begin{array}{l}\text { 'the opposite of' } \\
\text { opposite of' } \\
\text { the opposite of' }\end{array}$ & $\begin{array}{l}\text { cover } \\
\text { apply } \\
\text { please }\end{array}$ & $\begin{array}{l}\text { uncover } \\
\text { misapply } \\
\text { displease }\end{array}$ \\
\hline
\end{tabular}

The emboldened word organize is a 'verb', when the prefix re- 'again' is attached to it, it becomes reorganize 'change the way in which something is organized'. Both words, the root organize and the derived one reorganize are two different words having the same word class but different meanings. The verb organize means to arrange something or a part of something into a particular order or structure, whereas the new derived verb reorganize means to change the way in which something is organized.

Another example of verbal prefixes is shown when the prefix un- 'not' is attached to the verb cover, it becomes uncover which is also a 'verb'. Both words, the root cover and the derived one uncover, are two different words having the same word class but different meanings. The verb cover means "hide or protect" and "include", whereas the new derived verb uncover means "to remove something that covering something else" or "discover something that was previously hidden or secret” (Oxford Advanced Learner's Dictionary, 2015).

\section{4) Numeral Affixes}

The cardinal numerals remain cardinals when the suffixes -teen and $-t y$ are attached to them as shown below:

$\begin{array}{ccc}\text { Cardinal Numeral } & \text { Suffix } & \text { Cardinal Numeral } \\ \text { four } & \text { teen } & \text { fourteen } \\ \text { four } & \text { fy } & \text { forty }\end{array}$

The cardinal numbers can also be converted into ordinals when the suffix $-\boldsymbol{t} \boldsymbol{h}$ is added to them, as shown below:

\begin{tabular}{|c|c|c|}
\hline Cardinal Numeral & Suffix & Ordinal Numeral \\
\hline seven & $-t h$ & seventh \\
\hline seventy & $-t h$ & seventieth \\
\hline
\end{tabular}

In English, the class of numerals retains its grammatical categories when the suffixes -teen, -ty, and -th are attached to them.

\section{Conclusion}

As far as English Class maintaining derivational affixes are concerned, the following findings can be concluded:

1. Class maintaining derivational affixes can be added to the lexical categories of a noun, an adjective, a verb, and a numeral to form the same word classes with differences in meaning.

2. Class maintaining derivational affixes change the lexical meanings of the original words and retain their grammatical categories as summarized below:

a. Nominal affixes can be formed by attaching a prefix to a 'concrete noun' to form a new 'concrete noun', as well as by attaching a suffix to a 'concrete noun' to form an 'abstract noun'.

b. Adjectival affixes can be formed by attaching a suffix to an 'adjective to form new 'adjectives', as well as by 
adding a prefix to derive a new 'adjective'. In this category, prefixes contribute more than suffixes in the formation of adjectives within the class maintaining category.

c. Verbal affixes can be formed by adding a prefix only to a 'verb' to derive new verbs rather than by adding suffixes to derive other new verbs.

d. Numeral affixes can be formed by attaching the suffixes -teen and -ty to the 'cardinal numerals' to form new cardinals, as well as by adding the suffix - $\boldsymbol{t h}$ to 'cardinal numerals' to derive 'ordinal numerals'.

\section{Class Maintaining Derivational AfFiXes IN CENTRAL KURDISH}

\section{A. Theoretical Framework}

Derivational morphology is concerned with the internal structure of words. It deals with deriving new lexemes by attaching certain affixes that may change or maintain the class category of the newly derived words. In this section, class maintaining derivational affixes are introduced in the derivational words of the Kurdish language. Words are derived through various processes of word formation. One of these processes is derivation that is realized by affixation. According to Ali and Awl (2012, pp. 874-875) derivational morphology deal with forming new lexemes from the existing ones by affixation. Thus, derived words are those nouns that are the outcome of combining (root or base + derivational affixes) as summarized below:

\section{Derivational Prefixes Root/Base Derivational Nounss haw re hawre 'friend'}

Morphemes are defined as the words or parts of words that carry meaning and cannot be divided into smaller parts (Awl, 2010, p.312; Shwani, 2011, p.70). Morphemes can be free or bound, for instance, the diminutive suffix - ̌̌a 'smallness' can be added to the noun bax 'garden' to derive the noun baxča 'small garden'. From the derivational morphological perspective, in Kurdish, morphemes can be classified into roots and affixes. Roots are indivisible smallest parts of the words that carry the original meaning of the words after removing all the affixes (Dizayee, 2010, p.30; Marif, 1977, p.30; Amin, 1982, p.87). For instance, the word kič 'girl' is the root in all the following lexemes kič 'girl', kiča:na 'girlish', kičeni 'girlhood', kičoĺa 'little girl'. These lexical items are new nouns that are derived from the root kic 'girl' to convey different meanings while having the same syntactic category. In Kurdish, class maintaining category can be realized by affixation which can be subdivided into prefixes and suffixes. According to Awl (2010, p.316), prefixes are bound morphemes attached to the beginning of a root. Suffixes can be referred to as bound morphemes that are attached to the end of the word. Classmaintaining derivational affixes are described as deriving new lexical meanings from the existing lexemes without changing their grammatical categories. In Kurdish, words can be classified into simple and complex (Muhammad, 2011, p. 27). A complex word can be formed by a root verb such as $d a: n$ and an affix hal 'upward' to create a verb halda:n 'to throw upward' when the suffix -ewe 'the process of' is attached to it, it becomes halda:newe 'uncover by raising- listing up' (The Sharezoor Kurdish-English Dictionary, 2000, p. 585). The verb halda:newe is a complex word containing three morphemes, $\boldsymbol{h a l}$-, da:n, -ewe. Thus, the prefix hal- and the suffix -ewe are bound morphemes that cannot function as free-standing words (Muhammad, 2011, p. 26) and should be attached to other lexical items.

The following affixes contribute in the formation of 'nouns' from 'nouns', 'adjectives' from 'adjectives', 'verbs' from 'verbs', and 'numerals' from 'numerals':

\section{1) Noun Forming Affixes}

McCarus (1958, p.87) defines nominal suffixes as "those which convert to the form class of nouns". According to Marif (2014, p.131), some suffixes can change the subclasses of nouns, for instance, the suffix -sta:n 'the place of' changes the noun kurd 'the Kurds' into another noun Kurdistan 'the Kurdish homeland'. The suffix - č̂̀ 'maker' changes the noun boyax 'paint' into bayaxč ' 'painter', the suffix -en is attached to a noun halma:t 'marbel' to form the noun halma:ten 'game of marbles'. The following suffixes -dar, -ena, -ger, -emani, -saz, -mand, -ba:z and -kar can be attached to the nouns dukan 'shop', nisk 'lentil', asin 'iron', ši:r 'milk', da:n 'teeth', hunar 'art', sar 'head'; raw 'hunt' to derive the following new nouns dukandar 'owner of a shop', niskena 'lentil soup'; asinger 'blacksmith', širemani 'diary', da:nsa:z 'dentist'; hunarmand 'artist', sarba:z 'soldier' and 'ra:wkar 'hunter' (Marif, 2014, pp. $118,133)$.

Similarly, Ali and Awl state that the suffix -ewa:n 'one related to' can be attached to the nouns ba:x 'garden', $\check{s} a: x$ 'mountain', mala 'swimming' to form new nouns such as baxewa:n 'gardener', šaxewan 'mountainer', melewa:n 'swimmer' (2012).

According to McCarus (1958, pp. 87-88), the following suffixes -ayati, -ba:z, -č̂̀, -da:n, -ewari, -ga, -xan, and -za, can be attached to the nouns xizim 'relative', sag 'dog', boyax 'shoe shine', šekir 'sugar', kurd 'nation', dad 'court' žer 'under part', bra, 'brother' to derive the following new nouns, xizmayati 'relationship'; sagba:z 'dog fancier', boyaxčî 'bootblack' šekirda:n 'sugar bowl', kurdewari 'the Kurdish people', dadga, 'court', žerxan 'basement' bra:za, 'brother's child'.

In addition to that, McCarus (1958, p.88) and Marif (2014, pp. 21-22) mention that the diminutive suffixes such as -ula, očka and -ola 'the smallness of something' can be attached to the nouns meš 'fly', ma:l 'home', kiž 'girl' to derive the new nouns mešula 'mosquito', maločka 'little home' and kižola 'little girl'. The suffix -yila when it is attached to the noun angust 'finger', the noun angusti:la 'ring' will be formed (Marif, 2014).

On the other hand, nominal suffixes are often employed to derive "abstract nouns" (Bauer, 1983, p.109). In Kurdish, some affixes when they are attached to certain words, they can only change the subclasses of the given lexemes meaning that the changes occur within the same word classes. For instance, when the suffixes, $-\boldsymbol{e n i} \boldsymbol{i}, \boldsymbol{i}$, and $\mathbf{- a t} \boldsymbol{i}$ are added to the concrete nouns 
kič 'girl', mina:l 'child', pya:w 'man', they become abstract nouns kičên $\hat{\imath}$ 'girlhood' mina:lî 'childhood', and pya:watî 'manhood' (Marif, 2014, pp. 124-125; Awl, 2010, p.318).

\section{2) Adjective Forming Affixes}

McCarus (1958, pp. 90-91) introduces certain affixes that create adjectives from adjectives. The suffix - baw' of the shade of' and the negative prefixes $n e-$, $n a-$ 'not' when they are attached to adjectives sur 'red' and $x o s$ ' $p l e a s a n t$ ', the adjective surbaw 'reddish', nexoš 'ill' and na:xoš 'unpleasant' are formed. These negative prefixes have also been discussed by Marif (2014, p.114); Fattah and Hamawand (2014, pp. 47-49) and Hamawandy (2012, p.12). Moreover, Fattah (2012) lists four positive suffixes attached to certain adjectives including "ru:n $+\boldsymbol{a}, \boldsymbol{k}=$ ru:nak 'luminous'; kole + war $=$ kolewar 'severely handicapped'; der+îna = derîna 'a quality related to ancient time'; sipît+kele $=$ sipîkele "whitish"' $(\mathrm{pp} .176-179)$.

\section{3) Verb Forming Affixes}

Related to verb forming affixes, Marif (2014, p.114) mentions some of the Kurdish prefixes such as da- 'down', ra, $\boldsymbol{r} \boldsymbol{e}$ - 'used as first element of some derived forms', hal- 'up, $\boldsymbol{r} \boldsymbol{o}$ 'under', war-'cause to do the action', pe- 'reach the goal', and $\boldsymbol{t} \hat{\boldsymbol{e}}-, \boldsymbol{l} \hat{\boldsymbol{e}}$ - 'the act of' can be attached to the verbs girtin 'catch', xistin 'drop', ču:n 'go', gaštin 'grow or reach', kirdin 'to do', da:n 'give' to derive new verbs dagirtin 'get down', '́agrtin 'hold back', rexistin 'organization', halču:n 'to boil up', roču:n 'sinking', wargirtn 'receiving', pegai:štin 'grow to maturity; reach (one's goal)', têkirdin 'putting into', lêda:n 'hitting'. The suffixes -ewa and -din can be attached to the verbs gera:n 'search' and suta:n 'burn' to derive new verbs geŕanewa 'return' and sutandin 'burning' (The Sharezoor KurdishEnglish Dictionary, 2000, pp. 68-90).

Most of the above-mentioned affixes were introduced by Dizayee (2012, p.101) and Fattah and Hamawand (2014, p.3749); Fattah (2012, pp.176-179) who examined the uses and the meanings of some affixes. The meaning of the root or the base changes when the prefixes ra- 'controller', hel- 'up' -ewa 'repetition' are attached to girtin 'catch', gara:n 'search' and xwardin 'food' to form ra:grtin 'holding', helgara:n 'to climb up' and xwardnewa 'drinking'. When these prefixes are attached to the existing lexemes, they do not change the grammatical categories of the new words (Fattah and Hamawand, 2014, p.37-49; Awl, 2010, p.317).

\section{4) Numeral Forming Affixes}

In Kurdish, only suffixes can be added to a cardinal number to form new numerals. Marif outlines that derived numerals contain a simple word and a suffix such as $\boldsymbol{- a}$ in the cardinal numbers hafta 'seventy' and hašta 'eighty' (1998, pp.86-95). According to Marif (2014 [1977], p.114), Fakhry (2005, p.207) and Shwani (2011, p. 61) the suffixes (h)am, yak 'one' $+($ h) am = yak(h)am 'first'; and (ha)amin yak 'one'+ (h)amin

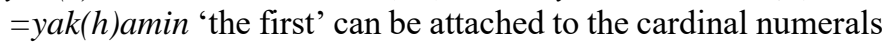
to form the ordinals. According to McCarus, these suffixes indicate a "position in a series of items" without change in meaning" (1958, p. 91).

\section{B. Analysis and Discussion}

In Kurdish, class maintaining derivational affixes do not alter the grammatical categories of the lexical items but only the meanings of the new lexemes. For instance, the lexical item froke 'airplane' is a 'concrete noun' when the suffix -wa:n is attached to it, the concrete noun frokewa:n 'pilot' will be formed and by affixing $-\hat{\imath}$ to it, the 'abstract noun' frokewa:n $\hat{\imath}$ 'pilot aviation career' will be formed. In this case, the suffixes $-\boldsymbol{w a}: \boldsymbol{n}$ and $-\hat{\boldsymbol{\imath}}$ are attached to a noun such as froke. Hence, the affixes $-\boldsymbol{w a}: \boldsymbol{n}$ and $-\hat{\boldsymbol{t}}$, are class maintaining suffixes.

The affixes summarized below retain the grammatical categories of the existing lexemes but change the meanings of the newly derived forms:

\section{1) Nominal Affixes}

The following affixes are attached to concrete nouns to form either concrete or abstract nouns:

Group 1: concrete nouns retaining concrete nouns by adding the following suffixes:

\section{Concrete Meaning Suffix Meaning Concrete}

Meaning

goza vase -lée samllness gozale 'small vase' bax 'garden' -če 'smallness' baxče 'small garden' bax 'garden' -awa,n 'one related to' baxawa:n 'gardener'

As shown in the above group (1), the emboldened item goza 'vase' is a 'concrete noun', when the suffix -le 'smallness' is attached to it, it becomes gozale 'small vase' which is also a 'concrete noun'. The changes occur in the meaning of the two lexemes, the former gives the meaning of $a$ vase while the latter refers to $a$ small vase. The emboldened noun bax 'garden' refers to an "area of grass" to grow "flowers, fruits, vegetables" while the derived noun baxewa, $n$ means 'gardener'.

Group 2: concrete nouns changing into abstract nouns by adding the following suffixes:

\section{Concrete Meaning Suffix Meaning Abstract Meaning \\ pyaw 'man' -ati 'state or condition' pya,wati 'manhood' \\ dost 'friend' -ayati 'state or condition' dosta:yati 'friendship' mina:l 'child' $-i \quad$ 'quality or state' min:ali 'childhood' \\ bra 'brother' -yati 'state or condition' bra,yati \\ 'brotherhood'}

\section{$\underline{\text { Prefix }} \underline{\text { Abstract }}$ Meaning Concrete Meaning haw- $\frac{\text { ka:r }}{\text { 'work' }}$ hawka:r 'co-worker'}

\section{2) Adjectival Affixes}

Adjectives can be converted into other adjectives by adding a prefix and a suffix as indicated below:

Group 1: Adjectives remain adjectives by adding the following prefixes: 
$\underline{\text { Prefix Meaning Adjective Meaning Adjective Meaning }}$ na- 'not' ya:sa:i 'legal' na:ya:sa:i 'illegal' ne- 'not' gunjaw 'suitable' negunjaw 'unsuitable'

The above emboldened lexical item ya:sa:i 'legal' is an 'adjective' when the prefix $\boldsymbol{n a -}$ is added to it, the negative adjective na:ya:sa:i 'illegal' is formed which conveys the opposite meaning of ya:sa:i. Hence, the changes occur in the meaning of the lexical items that convey a positive meaning in ya:sa:i, 'legal' and a negative one in na:ya:sai: 'illegal' rather than the grammatical categories of the two derived words.

Group 2: Adjectives remain adjectives by adding the following suffixes:

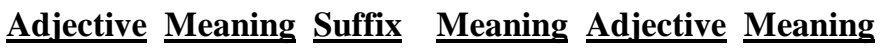
raš 'black' -baw 'of the shade of' rašbaw 'blackish' ru:n 'clear' -a:k 'having the quality' ru:na:k 'luminous' su:r 'red' -kele 'reducing the degree of' su:rkele 'reddish'

The emboldened lexeme su:r 'red' is an 'adjective' when the suffix -kele is added to it, the adjective su:rkele 'reddish' is formed which conveys 'reducing the degree of the colour'. Hence, the change occurs in the meaning of the lexical items su:r 'red' and su:rkele 'reddish', both referring to the colour red, but with a slight difference in meaning.

3) Verbal Affixes

Group 1: Verbs remain_verbs by adding the following prefixes:

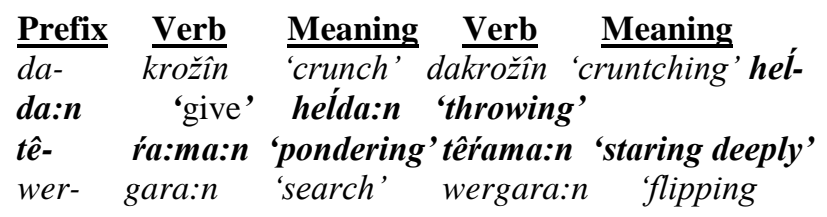

Group 2: Verbs remain verbs by adding the following

suffixes:

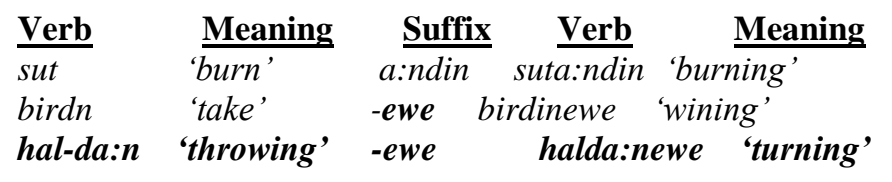

As shown in the classification of verbal affixes, the lexeme ra:man 'pondering' is a verb when the prefix tê- 'move in the direction of' is attached to it, it becomes têra:man 'staring deeply' which is a 'verb'. The change occurs only in the meaning of the two verbs while the grammatical category remains the same. When the prefix hel- 'up' is attached to a verb da:n 'give', a new verb helda:n 'throwing' can be formed. When the suffix - ewe emboldened in group (2) above is attached to this newly derived verb helda:n 'throwing', it derives another new verb heldanewe that can be used in different contexts and can have different meanings. However, it means 'to turn the page over' here used in the context of books. The original meaning of the verb hela: $n$ totally disappears, and a new meaning is formed. In the above list, the prefixes $d a-$, hel-, te- and wer- are class-maintaining derivational prefixes.

\section{4) Numeral Affixes}

Cardinal numerals remain cardinals by adding the suffix $-a$ : when this suffix is attached to the cardinal numerals hewt/ heft 'seven' and hešt 'eight', the cardinal numbers hefta: 'seventy' and hešta: 'eighty' are formed as shown below:

$\begin{array}{llll}\text { Cardinals } & \text { Meaning } & \text { Suffix } & \text { Cardinals } \\ \text { hewt/heft } & \text { 'seven' }-a: & \text { hefta: } & \text { seventy } \\ \text { hešt } & \text { 'eight' }-a: & \text { hešta: } & \text { eighty }\end{array}$

The cardinal numerals can be converted into ordinals by adding the suffixes, (h)am and $(h)$ amin.

\begin{tabular}{|c|c|c|c|c|}
\hline$\underline{\text { Cardinals }}$ & Meaning & $\underline{\text { Suffix }}$ & Ordinals & Meaning \\
\hline$\overline{y a k}$ & 'one' & $\overline{-(h) a m}$ & $\overline{\text { yak(ham) }}$ & 'first' \\
\hline yak & 'one' & $-(h) a m i n$ & yak(h)amin & 'first' \\
\hline pazda & 'fifteen' & $-(h) a m$ & pazda(h)am & 'fifteenth' \\
\hline$p a z d a$ & 'fifteen' & (h)amin & pazda(h)amin & 'fifteenth' \\
\hline
\end{tabular}

As shown in the above-mentioned types of numerals, when the suffix $-(\boldsymbol{h}) \mathbf{a m}$ is attached to the cardinal number yak 'one', the ordinal number yak(h)am 'the first' is formed. Similarly, when the suffix -(h)amin is added to the cardinal number yak 'one', the ordinal number yak(h)amin 'the first' is formed. The grammatical category of the existing numeral yak 'one' and the newly derived numerals yak(h)am and yak(h)amin 'the first' remain in the same class. The difference between these items lies in that the cardinal number yak 'one' is associated with 'quantity of something' while the ordinal numbers yak(h)am and yak(h)amin 'the first' show the order of something in a sequence.

\section{Conclusion}

As far as Kurdish class maintaining derivational affixes are concerned, the concluding findings are summed up below:

1. Class maintaining derivational affixes can be added to the lexical categories of a noun, an adjective, a verb, and a numeral.

2. Class maintaining derivational affixes change the lexical meanings of the original words and retain their grammatical categories:

a. Nominal affixes can be formed by attaching a prefix to a 'concrete noun' to form a new 'concrete noun' and also by attaching a suffix to a 'concrete noun' to form an 'abstract noun'.

b. Adjectival affixes can be formed by adding a suffix to an 'adjective to form new 'adjectives' and also by adding a prefix to derive another adjective. In this category, suffixes contribute more than prefixes in the formation of adjectives within the class maintaining category.

c. Verbal affixes can be formed by adding a prefix to a 'verb' to derive new verbs, as well as by adding a suffix to derive other new verbs.

d. Numeral affixes can be formed by adding a suffix $-a$ : to the 'cardinal numbers heft 'seven' and hešt 'eight' 
to form the cardinal numbers hefta: 'seventy' and hešta: 'eighty', as well as by attaching the suffixes (h)am and (h) amin to cardinal numerals to derive ordinal numerals.

\section{A COMPARATIVE APPROACH TO Class MAINTAINING IN STANDARD ENGLISH AND CENTRAL KURDISH}

In this section, the points of similarity and difference of class maintaining derivational affixes in English and Kurdish are examined. Those affixes that retain the grammatical category of the given lexemes can contribute to the changes of the meanings of the new lexemes.

\section{A. Points of Similarity and Difference}

In Standard English and Central Kurdish, class maintaining derivational affixes include those affixes that are attached to the existing lexemes to change the meanings rather than the grammatical categories of the newly derived lexemes. English and Kurdish can create various meanings within the same class category. They are similar in the formation of deriving new meanings of the newly added lexemes in a process called derivation. In both languages, more than one affix could be attached to derive new lexical items and the grammatical categories of the new lexemes are retained in a process called multiple affixations. In English, it is possible to add more than one suffix to the cardinal numerals. For instance, when the suffixes -teen and -ty are attached to the cardinal numbers seven and nine, the cardinals seventeen and seventy will be formed. The suffix - th can also be attached to the cardinal numbers seventeen and seventy to derive the ordinals seventeenth and seventieth.

In Central Kurdish, the concrete noun froke 'airplane' can be converted into another 'concrete noun' by attaching the suffix $\boldsymbol{w a : n}$ to form frokewa:n 'pilot' and by affixing $-\boldsymbol{i}$, 'state or quality', the 'abstract noun' frokewani, 'pilot aviation career' will be formed.

In both languages, class maintaining derivational affixes can be added to the lexical categories of a 'noun', an 'adjective' and a 'verb'. Only in Kurdish language, new words can be formed by a 'numeral' as explained below:

In the classification of nominal affixes, English and Kurdish are similar in that a 'concrete noun' remains a 'concrete noun' by adding certain suffixes. For instance, the suffixes $-i s t$ in English and -le 'smallness' in Kurdish can be added to the 'concrete nouns' cartoon and goze 'vase' to derive cartoonist and gozele 'small vase'. Simultaneously, the suffixes -hood 'state' in English and -yeti 'state or condition' in Kurdish can be added to 'abstract nouns adult and pya:w 'men' to derive the abstract nouns adulthood and pya:wetî 'manhood' (see III.B.1; IV,B,1 Group 2). In Kurdish, the suffixes -i, -ati, -yati, -a:yati 'state or condition' can be added to the 'concrete nouns' mina:l 'child', pya:w 'man', bra 'brother' and dost 'friend' to form the abstract nouns mina:li 'childhood', pya:wetî 'manhood', bra:yati 'brotherhood' and dosta:yati 'friendship'. While in English, the suffix 'hood' can be attached to the 'concrete nouns' child, man, brother and the suffix -ship can be added to the noun friend to derive the abstract nouns childhood, manhood, brotherhood and friendship, respectively.

In English, the prefix ex- 'former' can be added to a 'concrete noun' wife to derive a new concrete noun ex-wife, whereas in Kurdish, a prefix haw - can be added to an 'abstract noun' ka:r 'work' to form a 'concrete noun' hawka:r 'co-worker' (see III.B.1; IV, B, 1 Group 1).

In the classification of adjectival affixes, both languages are similar in that 'adjectives' can retain their grammatical categories and can add other new meanings to the new derived 'adjectives' by attaching a prefix and a suffix to the existing ones. For instance, the prefixes il- in English and $\boldsymbol{n a}$ - in Kurdish can be attached to the 'adjectives' logical and ya:sa:i, 'legal' to derive the negative adjectives illogical and na:ya:sa:i, 'illegal'. The suffixes -ish in English and -baw 'of the shade of' in Kurdish can be attached to 'color adjectives' green and reš 'black' to derive greenish and rešbaw 'blackish'.

In the classification of verbal affixes, English and Kurdish are similar in deriving new verbs by attaching prefixes to the existing verbs. For instance, the prefixes $r \boldsymbol{e}$ - in English and wer'cause to do the action' in Kurdish can be added to the verbs organize and gara,n 'search' to form the two verbs reorganize and wergara, $n$ 'flipping'. The two languages are different in that verbs in Central Kurdish have the capability of deriving a new verb by adding a suffix to the given verb such as birdn 'taken' when the suffix - ewe is attached to it, it becomes birdinewe 'winning'. Thus, the meaning of the existing verb birdin will be changed to a totally different meaning birdinewe, whereas in English, no apparent suffixes can be attached in the formation of deriving new verbs.

In the classification of numeral affixes, in English, the cardinal numerals two, three, four, etc. remain cardinals when the suffixes -teen and $-t y$ are attached to them. For instance, the cardinal numeral four when the suffix teen and -ty are attached to, it becomes fourteen and forty. In Kurdish, when the suffix $-a$ : is attached to the cardinal numbers hewt/heft 'seven' and hešt 'eight', the cardinals remain cardinals and the numbers hefta: 'seventy' and hešta: 'eighty' will be formed. These cardinal numbers in both languages belong to the same classes of numerals. In other cases, in both languages, when the suffixes $-\boldsymbol{t h}$ in English and (h)am and (h)amin in Kurdish are attached to the cardinal numerals seven and yak 'one', the ordinal numbers seventh, yak(h)am 'the first' and seventieth and yak(h)amin 'the first' are formed. This could be applicable for all the other cardinal numerals in both languages.

The above-mentioned comparative analysis is the answer of the first research question addressed in the methodology section of this paper:

What are the points of similarity and difference between Standard English and Central Kurdish as far as class maintaining derivational affixes are concerned?

The second addressed research question:

Can class maintaining derivational affixes be attached to the word classes of nouns, adjectives, verbs and numerals to derive new lexemes in Standard English and Central Kurdish? 
could be answered and fulfilled by explaining that in both languages class maintaining derivational affixes could be attached to the lexical categories of 'nouns', 'verbs' and 'adjectives' with no changes in the grammatical categories but rather with the new meanings of the existing 'nouns', 'verbs' and 'adjectives'. Only in Central Kurdish, the suffix -a: could be added to some cardinal numerals to derive other cardinal numerals.

\section{B. Findings}

In this paper, the following findings have been drawn:

1. In both languages, derivational affixes can retain the grammatical categories and can change the lexical meanings of the original lexemes.

2. Both languages are similar in the formation of deriving new meanings of the newly added lexemes by a process called derivation to derive new lexical items without changing their grammatical categories.

3. In English, two suffixes can only be attached to 'cardinal numerals' to form new 'cardinal' and 'ordinal numerals' while in Kurdish, more than one affix could be attached to 'concrete nouns' to derive 'abstract nouns' by a process called multiple affixations.

4. In both languages, class maintaining derivational affixes can be added to the lexical categories of a 'noun', an 'adjective', a 'verb', as well as a 'numeral'.

5. English and Kurdish are similar in that 'concrete nouns' could remain 'concrete nouns', as well as could convert into 'abstract nouns' by adding certain suffixes.

6. In English, a prefix can be added to a 'concrete noun' to derive a new 'concrete noun', whereas in Kurdish, a prefix can be added to an 'abstract noun' to form a 'concrete noun'.

7. Both languages are similar in that 'adjectives' can derive new 'adjectives' by attaching a prefix and a suffix to the existing lexemes.

8. English and Kurdish are similar in deriving 'new verbs' by attaching prefixes to the 'existing verbs', whereas in Kurdish verbs have the capability of deriving a 'new verb' by also adding a suffix to the 'existing verbs'.

9. In both languages, the 'cardinal numerals' remain 'cardinals' when the suffixes -teen and -ty are added in English and the suffix $-\boldsymbol{a}$ in Kurdish are added to the 'cardinal numerals' hewt/heft 'seven' and hešt 'eight'.

10. The suffixes - th in English and (h)am and (h)amin in Kurdish can be attached to the 'cardinal numerals' to derive the 'ordinal numerals'.

\section{REFERENCES}

Ali, B. \& Awl, M. (2012). Durstai Nawawai Nawi Nasa,da La Dyalekti Kirmanji Nawarastda [The Internal Structure of Non-Simple Nouns in the Standard Kurdish Dialects]. Al Ustath Journal, No 102, College of Education, IbnRushd, University of Baghdad, Baghdad.

Amin, W. O. (1982). Wuša \{Words\}. Nusari Kurd, No. 9.

Awl, M. O. (2010) Dabešbûnî Kirdarî Lêkdiraw Le Ŕwî Daŕištinw Erkewe \{Classification of Compounding Verbs from the Compositional and Functional Perspectives\}. Journal of Kurdology. Sulaimani.
Bauer, L. (1983). English Word-Formation. Cambridge, UK, Cambridge University Press.

Boskany, S. (2014). A Contrastive Analysis of Agreement in Standard English and Standard Kurdish. Haji Hashim Printing House Erbil.

Clark, V., Hecht, B., \& Mulford, R. (1986). Acquiring Complex Compounds, Affixes and Word Order in English. Linguistics p. 24, pp. 7-29.

Dizayee, A. M. (2012). Wišasazî Zimanî Kurdî [Kurdish Morphology]. Hewler, University of Salahaddin.

Dupanović, E. (2019). Class-Changing Prefixes in the English Language. DHS 2 (8) (2019), 73-88.

Fakhry, S. (2005). The Syntax of Numerals in Standard English And Standard Kurdish. Journal of Zankoy Sulaimani (ISSN). Part B, Issue 16, December 2005, pp. 197-212.

Fatah, A., Hamawand, Z. (2014). A Prototype Approach to Kurdish Prefixes. International Journal on Studies in English Language and Literature (IJSELL) Volume 2, Issue10, October 2014, PP 37 49 ISSN 2347-3126 (Print) \& ISSN 2347-3134 (Online).

Fattah, A. H. (2012). A Cognitive Grammar Analysis of Suffixes in English and Kurdish. University of Sulaimani, published $\mathrm{PhD}$ dissertation.

Hamawandy, A. (2012). Derivational Morphemes in English with Reference to Dialects in Kurdish, A Comparative Analysis. Kirkuk University Journal- Humanity Studies Vol. 7 No, 3.

Hornby, A., Turnbull, J., Ashby, M., Lea, D., Parkinson, D., Phillips, P., Francis, B., Webb, S. \& Bull, V., (2015). Oxford Advanced Learner's Dictionary of Current English. (9th ed.). Oxford, Oxford University Press.

Katamba, F. (1993). Morphology. London, The Macmillan Press.

Leningrad, A. (1986). Lexicology of the modern English language. 3rd ed. Moscow Higher School. BBK 81.2 Eng-923 A 84

McCarus, E. N. (1958). A Kurdish Grammar, Descriptive Analysis of the Kurdish of Sulaimaniya, Iraq. Washington, Washington Paladograph Company.

Muhammad, M. (2011). Zarawasazî Pêwana [Measure Terminology]. (2nd ed.) Hewler, Aras Publishing House.

Marif, A. (1998). Rézmanî Kurdî /Bergî Yekem / Morfolojî / Bešî Çwarem / Jmare w Aweĺkrdar (Kurdish Grammar/Volume One/ Morphology/ Part Four/Number and Adverb). Baghdad, Kurdish academic press.

Marif, A. (2014). Rêzzmanî Kurdî / Bergî Yekem / Morfolojî / Bešî Yekem / Naw (Kurdish Grammar/Volume One/ Morphology/ Part One/Noun). Hewler, Rojhalat Press and Publisher.

Marif, A. (2000). Rêezmanî Kurdî / Bergî Yekem / Morfolojî / Bešî Penjem / Krdar (Kurdish Grammar/ Volume One/ Morphology/ Part Five/ Verb). Sulaimani, Sardam Printing and Publishing House.

Qazzaz, S. (2000) The Sharezoor Kurdish-English Dictionary. Erbil, Aras Press and Publisher.

Somathasan M. (2018), The Study of Affixes (prefixes and suffixes), An ESL and Innovative Approach IJAR, -pdfs. semanticscholar.org

Stageberg, Norman C. (1981). An Introductory English Grammar. (4th ed.). USA, University of Northern Iowa.

Shwani, R. (2011). Wišasazy Zimanî Kûrdî, Lêkolînawayakî Pŕaktîkya [Kurdish Word Formation, A Practical Study]. Hewler, Mukryan Publishing House.

Umera-Okeke, N. (2007). Exploring Affixation in English. African Research Review Vol. 1 (3) 2007, pp. 9-35.

\section{APPENDIX}

\section{Key to Kurdish Phonemic symbols}

\section{1-Consonants:}

$/ \mathrm{p} /$ is a voiceless bilabial as in pi:r 'old'

/b/ is a voiced bilabial stop as in ba:wk 'father'

$/ t /$ is a voiceless dental stop as in ta:wa:n 'crime'

$/ \mathrm{d} /$ is a voiced dental stop as in da:n 'teeth'

$/ \mathrm{k} /$ is a voiceless velar stop as in kič 'girl' 
/g/ is a voiced velar stop as in gu:rg 'wolf'

/f/ is a voiceless labio-dental fricative as in bafir 'snow'

$/ \mathrm{v} /$ is a voiced labio-dental fricative as in mirov 'human' $/ \mathrm{s} /$ is a voiceless alveo-dental fricative as in ma:si 'fish'

$\mathrm{l} / \mathrm{l}$ is a voiced alveo-dental fricative as in zima:n 'tongue'

$/ \check{\mathbf{s}} /$ is a voiceless alveo-palatal fricative as in ša:no 'stage'

$/ \check{z} /$ is a voiced alveo-palatal fricative as in ža:n 'pain'

$/ \check{c} /$ is a voiceless alveo-palatal affricate as in čiya 'mount'

$/ \mathrm{j} /$ is a voiced alveo-palatal affricate as in jwa:n 'beauty'

$/ \mathrm{m} /$ is a voiced bilabial nasal as in maR 'sheep'

$/ \mathrm{n} /$ is a voiced dental nasal as in nawa 'generation'

$/ \mathrm{y} /$ Is a voiced velar nasal as in ha han 'bee'

$/ \mathrm{h} /$ is a voiceless glottal fricative as in hawir 'cloud'

$/ \mathrm{h} /$ is a voiceless pharyngeal fricative as in hawt

/1/ is a voiceless velarized lateral as in la:wa:z 'weak'

$/ \breve{1} /$ is a voiced dental lateral as in sa:I' 'year'

$/ \mathrm{r} /$ is a voiced alveolar flap as in ta:rik 'dark'

$/ \breve{\mathrm{r}} /$ is a voiced alveolar trill as in $\breve{\mathrm{ra}}$ :w 'hunting'

$/ \mathrm{x} /$ is a voiceless velar fricative as in xor 'sun'

$/ \breve{\mathrm{X}} /$ is a voiced velar fricative as in x̌amba:r 'sad'

$/ \breve{\mathrm{q}} /$ is a voiceless uvular stop as in q̆a:wa 'coffe'

/?/ is a voiceless pharyngeal fricative as in sa 'a:t 'hour'

$/ \mathrm{y} /$ is a voiced palato-alveolar glide as in ya:ri 'game'

/w/ is a voiced labiovelar rounded glide as in ča:w 'eye'

\section{2- Vowels}

/a/ low Standard unrounded, short vowel as in sar 'head' /a:/ low Standard unrounded, long vowel as in sha: 'king' /è/ mid very close front unrounded long vowel as in èš 'pain'

/i/ high close front unrounded short vowel as in pišt ' back'

/i:/ high close front unrounded long vowel as in hi:č 'nothing'

/u/ high open back rounded short vowel as in kur 'boy'

/u:/ high close back rounded long vowel as in du:r 'far'

/o/ mid open back rounded short vowel as in košik 'palace' 